\title{
THE PROBLEM AS A DEVELOPMENTAL RESOURCE
}

\section{Abstract}

The paper presents an attempt to treat psychological problems in their positive function, as a resource for personality development. Life at large may be treated as problem-solving. Conscious and satisfying living is not a problem-free one, but rather the living heading toward the 39 infantile problems toward profound existential and insoluble problems of an adult living which direct one's path of personal maturation. Any problem begins with a contradiction of two oppositions, and besides straightforward or compromise strategies of resolving the contradiction, an ultimate dialectical solution is also possible through ascending to a broader framework, scheme of things in which the initial contradiction dissolves, ceases to exist anymore. This way of solving the problem is the way of increased understanding and advanced personality development. The author has elaborated a specific group practice of working with participants' life problems based on the facilitation of experience processing. This Life Enhancement Work allows to identify inner barriers hampering the experience processing, and the participants become able to unveil the solution they have within themselves; the result is either transformation of the problem into a more mature one or its complete dissolution.

Keywords: psychological problems, difficulties, transformation of problem, dialectical logic.

The problem ultimately is a source of everything that orient us. We are used to broadly application of the word "problem" meaning everything undesirable. The expression "He has a problem." is used to refer that the person who is considered has some difficulties. This word usage is not totally appropriate; the differentiation of problem and task is defined (as it is said, a healthy person turns a problem to a task, and not healthy person vice versa) which is based, first of all, on the understanding that the problem consists of uncertainty, notanswered question when the task - challenge, containing a ready-made algorithm for the solution path. Transformation of the problem to the task means the removal of uncertainty, and together with question, the opposite transformation means complication of something, which is considered to be clear.

However, the problem is not necessarily something bad, which should be struggled 
against, removed and solved. "The soul life of a cultural person is full of problems; without which it is even inconceivable" (10, p. 185). Jung considers the existence of a problem, hesitations, uncertainties typical for consciousness, and their absence - for unconscious (10, p. 186). "In the unconscious, there are no problems" (10, p. 187). Very often, the problem is a source of progress of essential processes of development.

The aim of this paper is positive analyses of the problem as a source of personal development, and also an attempt of dialectical explanation of mechanisms of that development and explanation of the authorial practice of life enhancement work based on those mechanisms.

The development as a qualitative dynamic of the problem: K. Popper (9) presents the problem as a starting point not only for any scientific research but also generally for life: "If desired we could describe life as a problem-solving process, and living organisms - as the only complexes in the Universe who can solve problems" $(9$, p. 82). The problem is defined through violation of expectation, also for animals (9, p. 13) and not necessarily it should be realized (9, p. 82). Popper describes three stages cycle of problem-solving in science and in animals' behaviour: 1. The problem, 2. Solving attempts, 3. Elimination (exclusion) of unsuccessful problem-solving attempts. This cycle can be considered as something in between behaviourist trial and error model and feedback-based correction model in the physiology of activity of N. A. Bernstein. The essence of the cycle is the thesis about errors' inevitability and about the key role of their identification and discarding. Further developing this scheme of application to scientific cognition, Popper at some moment adds 4 elements to it: new problems arising from the critical discussion of unsuccessful attempts (theories) (9, p.32). In other words, the problems are not solved; rather, they are transformed into new problems.

The existence of the problem by itself is inevitable as long as we are alive, and the personal development is connected not as much with the existence of those problems rather with their quality. A. Maslow characterized the self-actualization as a personal development connected with the transformation from neurological or infant, "not true" life problems to "true", existential, inevitable, essences problems of a human being (13, p. 115), adding:" If you tell that you have a personal problem, I don't know whether you mean "Good!" or "So pity" until I get to know you better". Everything depends on its reasons" $(13$, p. 7$)$. There are problems which cause regret. There are problems which cause envy.

Problem-solving - from formal to dialectical logic. The problem always occurs on two incompatible opposites of thesis and antithesis, in favour of each of them there are arguments. In formal logic approvals and rejections of the same thing, A and no-A, can't be 
correct at the same time. That is the problem. How to solve that problem? The extremes, really, are not optimal, and reasonable solution is always in between them (2). The principle of golden mean has an important role not only in antic European philosophy but also in Confucian philosophy and in life practice (3). The analyses of modern scientific research of the most complicated wisdom phenomena show that the main criteria of wisdom are to avoid extremes and to find some balance in between opposites (7).

However, Goethe has argued with Aristotle saying that it is wrong to consider that in between to opposites is the truth - actually in between them is the problem. The idea of compromise, golden mean, of course, is an important step but it doesn't have dialectic. The dialectical approach to the problem solving of opposites is different, and it is presented as more important and heuristic in the context of the work, first of all, with psychological problems. Famous determination provided by Hegel. In order to eliminate the incompatibility between the thesis and antithesis that formal logic contests, one must rise to a higher level of consideration, carry out a dialectical synthesis and bring to such a scheme of understanding at a higher level, within the framework of which opposition will disappear. This key position has a significant role in the development and clinical psychologies.

Many years ago, I proposed the classification method of conflict resolution in different spheres: artistic creativity, science creativity, social relationships and life enhancement, separating 4 types of strategies, in principle general for these 4 situations. 1. Ignorance the problem is not noticed and not perceived. 2. Persistence - I see the problem, but I insist in my way of problem-solving. 3. Compromise - Finding options based on mutual concede. 4. Creative approach, which is based on a dialectical leap, on movement to the higher level of consideration and understanding in which the original contradiction doesn't exist anymore. The last one is described by Hegel as dialectical synthesis (4).

The classical model of applied system analysis of R. Ackoff consists well with this classification (1). Ackoff distinguishes 4 types of problem-solving with different effectiveness. The most effective is absolution, hoping that it would be solved itself. After that, there is an attempt to act in a usual way which in the best case brings to resolution. The third method is the development of an optimal solution, having given restrictions (solution). All of them don't change the structure or function of the system. The most effective way of solution, the $4^{\text {th }}$ one is the conversion of the system, in which the problem has arisen or the environment which makes the dissolution of the problem. These 4 types are attached to the four types of conflict resolution strategies described above.

\section{Life enhancement as an existential practice of understanding development.}

It is the solution of problems that is the essence of my practical life enhancement 
development which occurs at the intersection of existential psychotherapy, education, spiritual guidance, coaching and philosophical counselling $(5,8,12)$.

Life enhancement work (LEW), successfully tested in 2005-2009, happens in small groups of 10 to 20-22 people, during three full days. The target of LEW is to solve the life problems raised by the participants. The problem can be any life uncertainty which troubles the participant for months or years, and obstacles his productive and prosperous life.

It is considered a manifestation of disagreement between the participant's picture of the world (worldview, belief system) and his life, existence-in-the-world (14). The work proceeds from the assumption that the world is unique and relatively recognizable, that it applies general laws, violation or ignorance of which causes problems, and that, if the LEW process is organized correctly in the group, the disagreements in the picture of the world of the group members can be eliminated, and some laws governing it, can be derived inductively or deductively with a unanimous consensus of the group members based exclusively on their personal experience; when the individual characteristics are taken out of the parentheses, and the individual situation is taken into account only in the most general terms.

Prerequisite, underlying the LEW, is the provision that the source of problems is the unprocessed or inadequately processed life experience due to the limited or false understanding of the laws and cause-and-effect relationships that make up the world. The content of the work is a dialogical clarification of the participant's problems with his understanding of the world and facilitation of processing of his "uncertain" life experience, which leads to changes in the world picture (it is hardly possible to come to these changes in other ways). "Only the client has a compass: (11, p. 268). As a result of these changes, the problem itself is also transformed, as we will discuss below.

The only axiom that participants are proposed to accept without evidence is the following: each person has some needs that he starves to satisfy. Everything else is deductively derived from this axiom; in particular, all problems are considered as a result of a person's desire to satisfy his needs. This statement is similar in its ascertaining part to the central thesis of classical Buddhism, which states that the desires of people are the cause of their suffering, although the problems and suffering are not identical. At the same time, if the normative conclusion, which in Buddhism, consists in recommending getting rid of desires, and with the suffering, then the existential position is different: neither desire, nor problem, nor even suffering are considered a priori undesirable. Problems are considered as the price for satisfying one's needs, and whether this price is excessive or adequate is ultimately determined by participants themselves. Often the fact that it is realized that the 
problem is the price for something more significant leads to its solution - the problem ceases to be a problem.

The work begins with the participants presenting themselves and their problems, and is carried out with the problems of all participants in turn; moderator defines the operating procedure. At the same time, the problems of many participants will turn out closely interrelated; moreover, in each group reveals its own problematic dominant (usually not repeated in other groups), which, with some variations, is claimed by many participants (up to $50-60 \%$ ).

The group members state their problem, after which, in order to clarify the problem, they answer the questions of the moderator at first and then of the other members. Rhetorical questions are not recommended; it is better to formulate them differently. Questions focus on the participant's view of the world, in the context of which he comprehends his problem, and on expanding these semantic frameworks by relying on the personal experience of the participant and other participants.

Detailed analysis of the problem situation is not required; more important is the participant's own experiences and his picture of the world, considered by the participants and moderator from the point of view of their world picture. It happens that a participant sketch only the general contours of the problem with separate details, refusing to go into details; this does not interfere with working with this problem. No member of the group, including the moderator, has the right to evaluate any judgment or decision as true or not true if this assessment is not drawn up by consensus of all members of the group. Not a single example from personal experience can be shared with other situations and other people; it can be considered in the best case as a special case of a general law in respect of which the group has reached consensus.

The result of LWR quite often is either the transformation of the problem into another one, or its disappearance, dissolution, or deconstruction. Indeed, the problem is constructed by the subject in the semantic context of a certain picture of the world; a new understanding leads to a change in the structure of the picture of the world (which is a sign of understanding, in contrast, to simply building up information), into which the old composition of the problem no longer fits. This sometimes happens in silent mode, without direct work on the problem. Often, participants whose problems have not been discussed before, by the end of the group refuse to discuss their problem, explaining that it doesn't exist anymore; it has been resolved or has disappeared. This is explained by the fact that the problems of the participants are only a reason for work, and its true target is a picture of the world of its participants, a movement towards a new understanding. We construct all our psychological 
problems in the semantic context of a certain picture of the world. A new understanding and change in the picture of the world lead to a change in the general structure of our ideas about reality, into which the old construction of the problem no longer fits.

Earlier, I managed to identify and show that the expansion of understanding of the world is the only unique form in which the person is given his personal development (6). Unlike cognition, (the growth of new information without changing the structure of the world vision), the understanding may not be associated with the receipt of new information, but it is always a spasmodic change in structure, a restructuring of the picture of the world. And the development of understanding is that the transition from a problem of a lower level to problems of a higher level that move us, remaining in the form of questions that cannot be given ready-made answers. "Significant life problems are never resolved forever. If they once seem us to be solved, then this will only harm us. Apparently, the meaning and purpose of the existence of such problems are not to solve them, but to constantly work on them. This alone protects us from dullness and ossification" (10, p. 193). These questions themselves often propel us far more than the answers. Life enhancement work is direct work with understanding, through which it influences personal development.

\section{References}

Ackoff R., Chetiri tipa resheniya problem//Problemi upravlenija v socialnikh setyakh. [Four types of problem solving // Problems of social networks control.] V7. 2014. Ed. 10, pp. 12-15.

Ivanchenko G.V., Zabota o sebe: istorija i sovremennost. [Self-care: history and modernity], M.: Smysl, 2009

Confutsianskih traktat "Chzhun Yun": perevodi i issledovaniya/ [Confucian Treatise "Chzhun Yun": translations and research]. A. E Lukyanov, M.: Vost.Lit., 2003.

Leontiev D.A., Shans dlya tvorchestva (konflikti I strategii ikh razresheniya) [Chance for creativity (conflicts and strategies of their resolution] // Konflikt v konstruktiwnoj psikhologii: tezisi dokladov i soobshenii na 2-y nauchno-prakticheskoy konferentsii po konstruktivnoy psikhologii. [Conflict in constructive psychology: abstracts of reports and articles on the 2 nd scientific-practical conference of constructive psychology] Krasnoyarsk, 7-10 June 1990 - Krasnoyarsk, 1990, pp. 17-20

Leontiev D.A. Zhiznetvorchestvo kak praktika rasshireniya zhiznennogo mira [Life Enhancement as a practice of extension of the life-world]. 1 Vserossiiskaya nauchno- prakticheskaya konferentsiya po ekzistentsial'noi psikhologii: Materialy 
soobschenii [1st Russian national scientific and practical conference in existential psychology: Proceedings]. Moscow: Smysl, 2001, pp. 100-109.

Leontiev D.A., Psikhologiya smisla 3 izd. dopoln [Meaning psychology, 3rd edition]. M.: Smysl, 2007

Leontiev D.A., Vozmozhnost mudrosti //Chelovek. [Wisdom opportunity// A person], 2011. N1, pp.20-34

Leontiev D.A., Opyt metodologicheskogo osmysleniya praktik raboty $s$ lichnost'yu: fasilitatsiya, nootekhnika, zhiznetvorchestvo [Making methodological sense of practices of personality interventions: facilitation, nootechnics, life enhancement]. Konsul'tativnaya psikhologiya i psikhoterapiya [Counseling Psychology and Psycho- therapy], 2012, N. 4(75), pp. 164-185.

Popper K., Vsya zhizn - reshenie problem: O poznanii, istorii I politike. Chast 1. Voprosi poznaniya prirodi. [Whole life - problem solving. About cognition, history and politics. Volume 1. Nature cognition issues], M. URSS, LENAND, 2019

Jung K.G. Problemi dushi nashego vremeni [Soul problems of nowadays], M., Progress, Universe, 1993 